\title{
Segregation of a major gene influencing ovulation in progeny of Lacaune meat sheep
}

\author{
Loys Bodin $^{\mathrm{a} *}$, Magali SANCRISTOBAL ${ }^{\mathrm{b}}$, \\ Frédéric LeCERF $^{\mathrm{b}}$, Philippe Mulsant ${ }^{\mathrm{b}}$, Bernard Bibéc ${ }^{\mathrm{c}}$, \\ Daniel LAJous ${ }^{\mathrm{a}}$, Jean-Pierre Belloc ${ }^{\mathrm{d}}$, Francis Eychenne ${ }^{\mathrm{e}}$, \\ Yves Amigues $^{f}$, Jean-Michel ELSEN ${ }^{\mathrm{a}}$ \\ a Station d'amélioration génétique des animaux, \\ Institut national de la recherche agronomique, \\ BP 27, 31326 Castanet-Tolosan, France \\ ${ }^{\mathrm{b}}$ Laboratoire de génétique cellulaire, \\ Institut national de la recherche agronomique, \\ BP 27, 31326 Castanet-Tolosan, France \\ ${ }^{\mathrm{c}}$ Département de génétique animale, \\ Institut national de la recherche agronomique, \\ BP 27, 31326 Castanet-Tolosan, France \\ ${ }^{d}$ Coopérative OVI-TEST, Route d'Espalion, \\ 12850 Onet-le-Château, France \\ e Domaine expérimental de Langlade, \\ 31450 Montgiscard, France \\ f Labogena, Domaine de Vilvert, 78352 Jouy-en-Josas, France
}

(Received 17 September 2001; accepted 13 February 2002)

\begin{abstract}
Inheritance of the ovulation rate (OR) in the Lacaune meat breed was studied through records from a small nucleus of 36 hyper-prolific ewes screened on farms on the basis of their natural litter size, and from progeny data of three selected Lacaune sires. These sires were chosen at the AI centre according to their breeding values estimated for the mean and the variability of their daughters' litter size. Non-carrier Lacaune dairy ewes were inseminated to produce $121 \mathrm{~F} 1$ daughters and $27 \mathrm{~F} 1$ sons. Twelve sons (four from each sire) were used in turn to inseminate non-carrier Lacaune dairy ewes providing $260 \mathrm{BC}$ progeny ewes. F1 and BC progeny were brought from private farms and gathered after weaning on an experimental farm where ovulation rates were recorded in the first and second breeding seasons. With an average of 6.5 records each, the mean OR of hyper-prolific ewes was very high (5.34), and $38.4 \%$ of records showed a rate of 6 or more. F1 data showed high repeatability of OR $(r=0.54)$ within ewe, with significant variability among ewes. High OR $(\geq 4)$ were observed in each
\end{abstract}

\footnotetext{
* Correspondence and reprints
}

E-mail: bodin@toulouse.inra.fr 
family. A segregation analysis provided a significant likelihood ratio and classified the three founders as heterozygous. BC ewes also displayed high repeatability of OR $(r=0.47)$ and the mean OR varied considerably between families (from 1.24 to 1.78). Seven of the $12 \mathrm{BC}$ families presented high-ovulating ewes (at least one record $\geq 4$ ) and segregation analysis yielded a highly significant likelihood ratio as compared to an empirical test distribution. The high variability of the mean ovulation rate shown by a small group of daughters of $\mathrm{BC}$ ewes inseminated by putative carrier F1 rams, and the very high ovulation rate observed for some of these ewe lambs, confirmed the segregation of a major gene with two co-dominant alleles borne by an autosome. The difference between homozygous non-carriers and heterozygous ewes was about one ovulation on the observed scale and 2.2 standard deviations on the underlying scale.

sheep / major gene / ovulation

\section{INTRODUCTION}

Since 1982, when evidence of the first major gene for prolificacy was found by Piper and Bindon [23], and Davis et al. [7] in Booroola Merinos, various authors like Hanrahan and Owen [13], Hanrahan [12], Jonmundsson and Adalsteinsson [17], Bradford et al. [4], Radomska et al. [26], and Davis et al. [5] have suspected or demonstrated that ovulation in other sheep breeds could also result from mixed (polygenic background + major gene) inheritance. In addition, Galloway et al. [11] have found the DNA mutation responsible for the Inverdale genotype shown by Davis et al. [6,8]. Moreover Mulsant et al. [20] and Wilson et al. [30] have discovered the DNA mutation for the Booroola genotype. The Lacaune breed with 1.2 million ewes is the major French sheep breed. Several strains exist, each being bred for a specific purpose i.e. milk or suckling lamb production. In 1975, the artificial insemination co-operative (OVI-TEST) implemented an on-farm selection scheme designed to improve prolificacy [22]. During the first 20 years, natural prolificacy was the main objective, but significant progress then led to consider new objectives like meat traits. The large and fast selection response for prolificacy, reputed to be difficult to select for, together with several other indications suggested non polygenic inheritance of prolificacy in this selected population. The main points observed were:

- A fast and high response to selection. The mean prolificacy of ewe lambs mated in June-July at about 11 months of age was 1.28 in 1975 [2]. Using similar management, at the same age and season, prolificacy was 1.98 in 1996 for five pioneer flocks, which were the only flocks that had been under selection since 1975.

- The occurrence of an exceptionally high litter size. Some ewes presented repeatedly exceptional prolificacy $(\geq 4)$ when compared to the population mean. The number of these hyper-prolific ewes has increased very quickly over the last few years. 
- A very high heritability coefficient for the litter size $\left(h^{2} \sim 0.4[1,27]\right)$, which did not agree with conventional values as expressed in the literature. As quoted by Le Roy and Elsen [18], high heritability coefficient values are the first indicators of segregation of a major gene.

- It was also observed that some sires with very high breeding values, as estimated using a sire model through performance of their daughters, had very low breeding values when estimates were made through performance of their granddaughters alone [3]. Assuming there to have a dominant major gene controlling prolificacy, sons of these sires could have inherited the wrong alleles of this segregating gene.

- Preliminary segregation analysis performed on litter size recorded within the nucleus led to the rejection of a strictly polygenic inheritance of prolificacy [9].

- Estimations of genetic components of litter size with a heteroscedastic model as developed by SanCristobal-Gaudy et al. [28] showed variances between sires to be heterogeneous.

However, none of these observations constituted formal proof of the existence of a major gene, and a specific program aiming to observe possible gene segregation was devised in order to clarify the situation [3]. This program is based on the hypothesis that prolificacy in the Ovitest Lacaune strain is partially controlled by a major gene with two alleles: L (inducing higher ovulation) and + (or wild). The results of these observations are reported in the present paper.

\section{MATERIALS AND METHODS}

Two experiments were set up in order to determine the existence of a putative major gene in the Lacaune population managed by OVI-TEST. The first concerned the screening on farms of a few hyper-prolific ewes and the observation of their ovulation rates over several cycles on an experimental farm. The second aimed at observing the segregation of the putative gene within half-sib progeny of three potential carrier sires and of twelve of their sons back-crossed to non-prolific Lacaune strains.

\subsection{Establishing a nucleus of hyper-prolific Lacaune ewes}

\subsubsection{Screening of ewes on farms}

In July 1996 and 1997, extensive screening of hyper-prolific ewes was carried out on about 40 farms in the OVI-TEST selection scheme. Selection was made in a population of about 10000 adult ewes, although only those which were neither pregnant nor suckling at the dates of screening were considered. A very small sample (18 ewes each year) was selected on the basis of breeding 
value for prolificacy as estimated by the national recording system [24], and of their own performance. They had lambed more than twice in natural conditions (without oestrus synchronisation), and had had either a litter size $\geq 3$ twice, or a litter size $\geq 5$ once. They were brought from private farms to Langlade: an Inra experimental centre.

\subsubsection{Ovulation rate controls}

Ovulation rates were recorded several times (up to 12) by laparoscopy, either during an induced cycle, five to eight days after oestrus synchronisation (a vaginal sponge inserted for 14 days without PMSG at withdrawal), or during the two following cycles (three and six weeks after the first observation).

\subsection{Progeny test design}

\subsubsection{Animals}

In April 1996, the 157 Lacaune sires then in the OVI-TEST selection scheme AI Centre had their breeding values estimated using a heteroscedastic model fitting the natural prolificacy of their daughters. This model [27] allows individual breeding values for the mean (u) and for the variability of litter size (v) to be estimated together. Three rams were chosen for having high breeding values for the mean litter size and for the litter size variability of their daughters, and were consequently thought to be heterozygous for the putative major gene. These three rams were used for artificial insemination of 178 adult Lacaune dairy ewes (a reputedly non-prolific strain) on six private farms, and of 72 adult Lacaune ewes of the "Gebro strain" (a Lacaune strain of suckling ewes known not to be prolific) on the Inra Langlade farm. "F1" ewe lambs born on the private farms from these inseminations were bought after weaning at two months of age $(n=86)$ and put together with those born on the experimental farm $(n=35)$. F1 ram lambs $(n=24)$ born on the private farms were also bought by the OVI-TEST insemination centre and reared as semen producers. Three other F1 rams born from the AI carried out on the Langlade farm were also kept and reared as future semen producers. In August 1997, twelve of these sons (11 born on private farms from Lacaune dairy ewes and one born on the Langlade farm from a Gebro Lacaune ewe) were then used to inseminate dairy or Gebro Lacaune ewes (respectively 716 and 65 adult ewes). As with the first generation, after weaning, back-cross (BC) ewe lambs were gathered on the Langlade farm $(n=260)$. At the end of their first breeding season, and after three ovulation records, a small sample of high-ovulating BC ewes were selected and inseminated with semen from six F1 rams which were expected to be $\mathrm{L}+$ (heterozygous for the putative major gene) on the basis of the first three OR of their daughters. Ewe lambs $(\mathrm{F} 1 \times \mathrm{BC} ; n=31)$ born of these inseminations were kept for control purposes. The other $\mathrm{BC}$ ewes were inseminated by Ile-de-France rams for lamb production. 


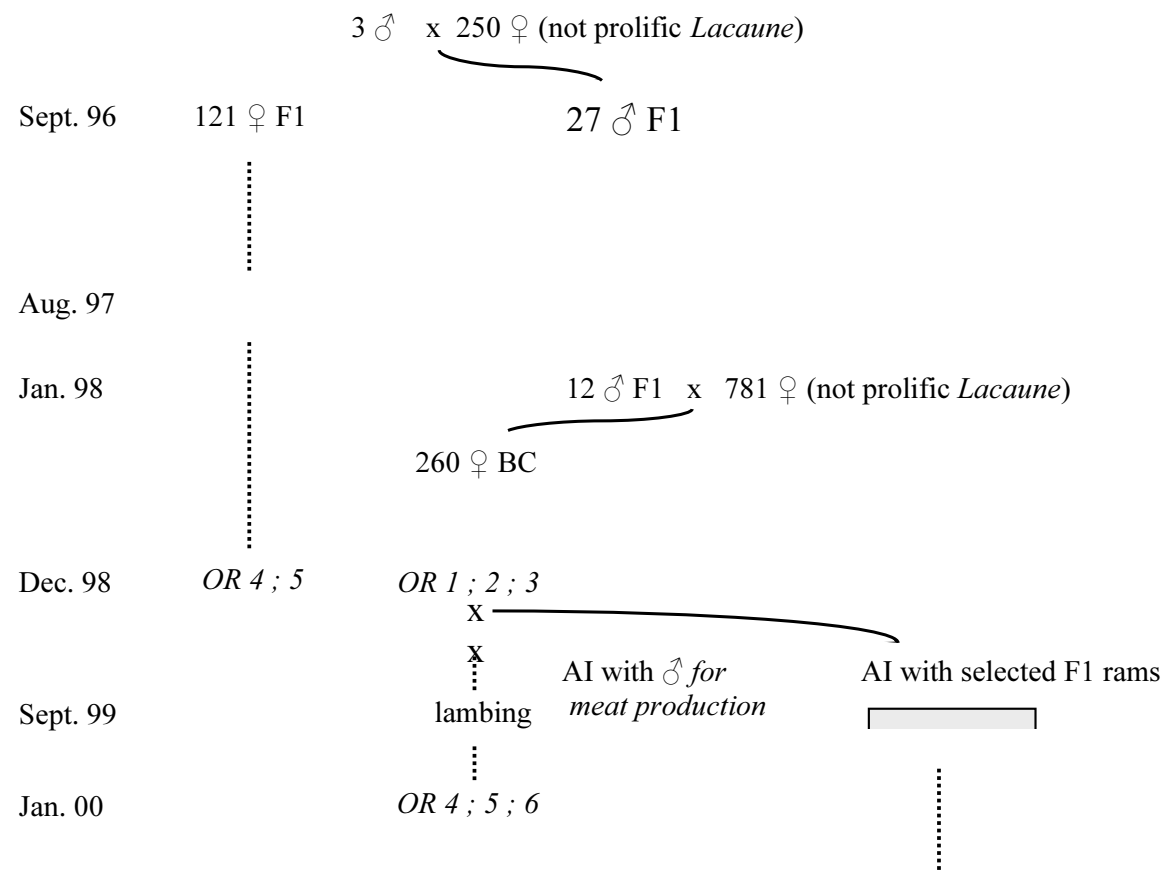

Aug. 00

Figure 1. Schedule and design of the progeny test of three putative carrier sires.

\subsubsection{Phenotype observations}

Oestrus in the $\mathrm{F} 1$ and $\mathrm{BC}$ ewe lambs was synchronized using a vaginal sponge (without PMSG injection) when they were about eight months old. In order to determine the ovulation rate, numbers of corpora lutea were counted using laparascopy between four and eight days after sponge withdrawal and then three and six weeks later for the two subsequent cycles. When they were 24 months old, laparoscopy was again performed on the F1 and BC ewes two and three times respectively. Figure 1 summarises the schedule of this experiment. It is worth noting that after the first series of observations and mating, the BC ewes, which lambed, reared their lambs until weaning at about three months of age.

All animals in this program were bled and the extracted DNA was used for confirmation of paternity, and frozen for future research of DNA markers.

\subsection{Statistical analysis}

Variation factors of OR to be included in the later segregation analysis were determined by BLUP on the F1 data using the Proc mixed procedure 
$\left(\mathrm{SAS}^{\circledR}\right)$ and considering four fixed effects: the origin of the dam (Dairy or Gebro Lacaune ewes); the laparoscopy number which includes the effects of date and age (8 and 24 months); the suckling state (not having lambed, or long interval since weaning $v s$. short interval since weaning) and the founder sire. The ewes nested within their respective sire were considered as random effects. For the $\mathrm{BC}$ data, similar analyses were performed considering the same four fixed effects, but in this case, the sires nested within the grandsire and the ewes nested within their respective sire were considered as random effects; no relationships between random effects were considered. Variance components of OR (on the observable scale) were estimated by REML, and finally heritability was calculated regarding the sire variance as a quarter of the additive genetic variance.

As in Le Roy et al. [19] and Ilahi et al. [16], a segregation analysis method was run, comparing likelihoods under two inheritance hypotheses:

- H1: mixed inheritance hypothesis. This model describes the transmission of ovulation rate ability by polygenic effects to which a major gene effect is added. The model assumes that the observed ovulation rate is related to an underlying normal distribution rate and to a set of fixed thresholds which impose discontinuity in its visible expression. We assume that only two alleles $(\mathrm{L}$ and +$)$ segregate and, according to the particular pattern of crosses, that two or three genotypes can be encountered: LL, L + and ++ . The parameters to be estimated are: the thresholds, the mean of each genotype $(\mu++, \mu \mathrm{L}+, \mu \mathrm{LL})$, and their respective frequency $(\mathrm{p}++, \mathrm{pL}+$ and $\mathrm{pLL})$, for the sires. Parameters that have been fixed in the model are: the allele frequencies for the dams $(\mathrm{p}++=1.0$ while $\mathrm{pL}+$ and $\mathrm{pLL}=0.0)$, as well as heritability $\left(h^{2}=0.29\right)$ and repeatability $(r=0.42)$; these values coming from previous analyses of a large data set of Mérinos d'Arles ovulation rates are much more precise than parameters estimated in the present sample.

- H0: polygenic inheritance hypothesis. This model, which is a sub-model of the H1 mixed inheritance hypothesis, merely assumes that: $\mathrm{p}++=1$ for the sires.

The likelihoods $\ell_{0}$ and $\ell_{1}$ were computed respectively for the hypotheses $\mathrm{H} 0$ and $\mathrm{H} 1$, and the ratio $L=-2 \log \left(\ell_{0} / \ell_{1}\right)$ compared with a threshold $\tau$. The estimation of parameters maximising the likelihoods was carried out using the Gauss-Hermit quadrature (D01BAF) and optimisation (E04JYF) subroutines of the NAG FORTRAN Library [21] with a quasi-Newton algorithm in which the derivatives were estimated by finite differences.

A first segregation analysis was performed on the F1 data. The model considered five ovulation rates of the F1 daughters, progeny of the three founder sires and 128 homozygous ++ dams. It also included the fixed effects which were found significant in the previous analysis: the age when laparoscopy was 
Table I. Empirical thresholds of rejection of the $\mathrm{H} 0$ hypothesis deduced by segregation analysis of 1200 samples randomly simulated under the $\mathrm{H} 0$ hypothesis.

\begin{tabular}{ccc}
\hline Threshold $=\tau$ & Number of replicates with $L>\tau$ & Corresponding $\alpha$ risks \\
\hline 4.26 & 120 & 0.10 \\
6.04 & 60 & 0.05 \\
10.12 & 11 & 0.01 \\
13.31 & 1 & 0.001 \\
\hline
\end{tabular}

carried out, and the origin of the dam. A second analysis was performed on the six OR records of the $\mathrm{BC}$ population, progeny of the 12 sons of the founders and 228 homozygous ++ dams. It considered the grand-sire, the age at which laparoscopy was carried out, the origin of the dam and the rearing status as fixed effects. Ewes classified as L+ had a probability of over 0.85 , while those classified as ++ had a probability of less than 0.15 ; for $\mathrm{L}+$ sires the minimum probability was 0.98 .

The polygenic inheritance hypothesis is rejected when $L>\tau$. The exact distribution of the likelihood ratio is unknown. Usually, a $\chi^{2}$ test is performed with the degrees of freedom equal to the number of parameters to be fixed for going from $\mathrm{H} 1$ to $\mathrm{H} 0$. However, as noticed by Titterington et al. [29], this rule does not apply in mixture analysis. We therefore carried out similar analyses on two Booroola data samples of comparable size in which we knew that a major gene was segregating. We also computed an empirical rejection threshold from simulations. The actual structure of pedigree and performance of the BC populations ( 242 daughters of 12 sires and 228 dams; six records of OR) was used to generate 2000 replicates under polygenic transmission which were submitted to segregation analysis. The rejection thresholds with desired $\alpha$ risks are directly given by the distribution of the likelihood ratio and are summarised in Table I.

\section{RESULTS}

\subsection{Ovulation of hyper-prolific ewes}

The ovulation rate distribution observed in the small nucleus of hyper-prolific ewes is given in Figure 2. The mean ovulation rate was very high $(\mu=5.34$; $n=229)$, with $24.7 \%$ of recorded rates being $\geq 7(38.9 \% \geq 6)$ while only $20.3 \%$ were $\leq 3$. The maximum observed was 20 , and single ovulation was observed only twice. The two highest-ovulating ewes presented an average of 12.4 and 11.5 corpora lutea respectively over five and six records. 


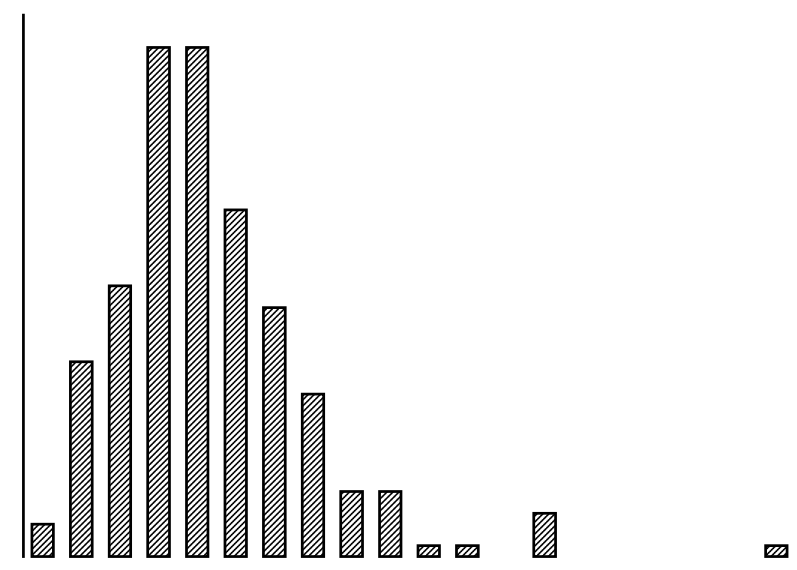

Figure 2. Distribution of ovulation rates observed in the small hyper-prolific nucleus.

\subsection{Ovulations of $F 1$ daughters}

Distribution of ovulations in F1 daughters of the three founders is displayed in Table II. In the first set of observations in July-August 1997, the ewe lambs were relatively young and for this reason a high percentage did not respond to the synchronisation treatment used without PMSG injection. Thus, 37.2, 61.4 and $33.6 \%$ of the ewes did not ovulate in the first, second and third observations respectively. In contrast, when these F1 ewes were two years old, very few did not ovulate $(<2 \%)$.

The mean ovulation rate was 2.04 at 11 months of age (1.86, 2.11 and 2.13 respectively for the three founders), increasing in the second year $\left(\mathrm{OR}_{2 y}=3.03\right)$ with $68.80 \%$ the ewes displaying at least once an ovulation rate of three or more. These high-ovulating ewes were found in each family. Among ewes with three ovulation records during their first year, two sets of ewes with significant differences in OR could be clearly observed in each family, respectively: 1.30 and $2.29-1.44$ and $2.73-1.38$ and 2.60 .

Variance analysis considering the sire (founder sires) and the date of observation (1 to 5) as fixed effects, and ewe within sire as a random effect, enabled ovulation rate repeatability $(r=0.54)$ and a small but significant difference between sires to be estimated. Segregation analysis using these data (5 OR per female; 372 records) yielded a likelihood ratio of 14.3 (Tab. V). Based on this analysis, the three founders were classified as heterozygous and the effect of the gene was found to be 1.09 ovulation on the observed scale and 1.72 standard deviations on the continuous underlying scale. 
Major gene for ovulation rate in Lacaune sheep

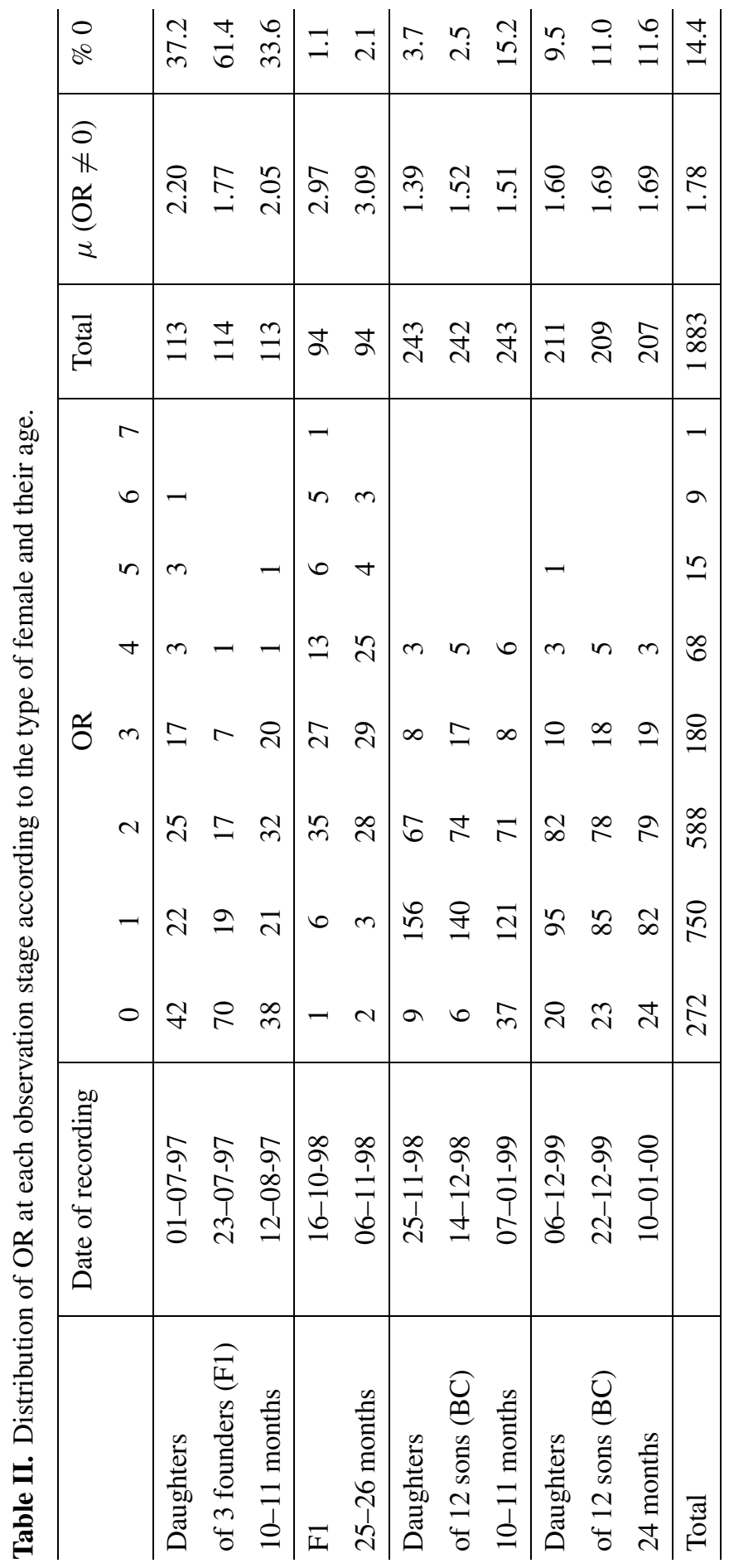


Table III. Sire effect on OR of the BC daughters.

\begin{tabular}{lcccccc}
\hline Sire $^{\dagger}$ & Geno. $^{*}$ & $\begin{array}{c}\text { Ewe } \\
\text { number }\end{array}$ & $\begin{array}{c}\text { Number } \\
\text { of rcds }\end{array}$ & $\begin{array}{c}\text { Standard } \\
\text { deviation }\end{array}$ & CV & Lsmeans \\
\hline A_104 & L+ & 11 & 52 & 0.81 & 0.46 & 1.66 \\
A_108 & L+ & 19 & 98 & 0.74 & 0.45 & 1.58 \\
A_114 & ++ & 19 & 103 & 0.48 & 0.36 & 1.27 \\
A_118 & ++ & 15 & 75 & 0.49 & 0.38 & 1.25 \\
B_109 & L+ & 14 & 61 & 0.85 & 0.50 & 1.62 \\
B_115 & L+ & 21 & 92 & 0.91 & 0.49 & 1.76 \\
B_121 & ++ & 20 & 107 & 0.57 & 0.42 & 1.28 \\
B_122 & L+ & 17 & 80 & 0.91 & 0.50 & 1.78 \\
C_102 & L+ & 13 & 64 & 0.96 & 0.53 & 1.77 \\
C_110 & L+ & 25 & 130 & 0.77 & 0.48 & 1.55 \\
C_119 & ++ & 22 & 121 & 0.48 & 0.37 & 1.24 \\
C_960856 & ++ & 46 & 253 & 0.54 & 0.35 & 1.50 \\
\hline Total & & 242 & 1236 & & & \\
\hline
\end{tabular}

$\dagger$ The first letter indicates the founder family.

\# According to the segregation analysis.

\subsection{Ovulation of $\mathrm{BC}$ ewes}

When they were less than one year old, the $245 \mathrm{BC}$ ewe lambs presented a lower ovulation rate $\left(\mathrm{OR}_{11 \mathrm{~m}}=1.47\right)$ than the $\mathrm{F} 1$ ewes at a similar age $\left(\mathrm{OR}_{11 \mathrm{~m}}=2.04\right)$. However, in spite of this young age very few failed to ovulate (Tab. II) in the first two series of observation in full breeding season (3.7 and $2.5 \%$ respectively in November and early December), while for the last series, which occurred in January, some ewe lambs had already finished their first breeding season and did not ovulate $(15.2 \%)$. Ovulation rates were higher when ewes were older (Tab. II), but the increase with age was not as high as that observed for the F1 ewes. Variance analyses were also performed on F1 data with a model considering as fixed effects the origin of the dam (dairy or Gebro Lacaune ewe), the grandsire, the date of observation and the suckling status, and as random effects, sire and ewe within sire. Repeatability was estimated at 0.48 and heritability at 0.30 . However, considering the sire as a fixed effect showed significant differences among sires (Tab. III).

From the distribution of the greatest OR of each ewe (Tab. IV), it can be seen that there are two groups of sire family according to the percentage of daughters displaying an ovulation rate of three or more ( $\circ \mathrm{OR} \geq 3$ ) at least once, recorded at about 11 months of age. Addition of ovulation rates recorded 
Table IV. Distribution of the highest ovulation rate in BC ewes per sire family.

\begin{tabular}{|c|c|c|c|c|c|c|c|c|c|c|}
\hline \multirow[b]{2}{*}{ Sire } & \multirow[b]{2}{*}{ Geno. $^{\dagger}$} & \multicolumn{2}{|c|}{$\%$ of $q \mathrm{OR}>3$} & \multicolumn{6}{|c|}{$\begin{array}{c}n \text { of } q \text { with at least } \\
\text { once OR }>\text { than }\end{array}$} & \multirow[t]{2}{*}{$n$} \\
\hline & & $<1$ year & global & $\overline{0}$ & 1 & 2 & 3 & 4 & 5 & \\
\hline A_104 & $\mathrm{L}+$ & 0.27 & 0.45 & 1 & 1 & 5 & 4 & 1 & & 12 \\
\hline A_108 & $\mathrm{L}+$ & 0.16 & 0.42 & & 5 & 6 & 6 & 2 & & 19 \\
\hline A_114 & ++ & 0.00 & 0.00 & & 6 & 13 & & & & 19 \\
\hline A_118 & ++ & 0.00 & 0.07 & & 6 & 8 & 1 & & & 15 \\
\hline B_109 & $\mathrm{L}+$ & 0.14 & 0.29 & & 5 & 5 & 2 & 2 & & 14 \\
\hline B_115 & $\mathrm{L}+$ & 0.33 & 0.38 & & 3 & 10 & 5 & 2 & 1 & 21 \\
\hline B_121 & ++ & 0.05 & 0.20 & 1 & 5 & 11 & 4 & & & 21 \\
\hline B_122 & $\mathrm{L}+$ & 0.29 & 0.35 & & 4 & 7 & 3 & 3 & & 17 \\
\hline C_102 & $\mathrm{L}+$ & 0.31 & 0.38 & & 4 & 4 & 1 & 4 & & 13 \\
\hline C_110 & $\mathrm{L}+$ & 0.20 & 0.32 & 1 & 6 & 11 & 5 & 3 & & 26 \\
\hline C_119 & ++ & 0.05 & 0.05 & & 6 & 15 & 1 & & & 22 \\
\hline C_960856 & ++ & 0.04 & 0.09 & & 7 & 35 & 3 & 1 & & 46 \\
\hline Total & & 0.14 & 0.22 & 3 & 58 & 130 & 35 & 18 & 1 & 245 \\
\hline
\end{tabular}

${ }^{\dagger}$ According to the segregation analysis.

at two years of age allowed the same families to be distinguished, and it is worthwhile noting that the increase of $o \mathrm{OR} \geq 3$ with age was generally very low in families where the percentage observed at about 11 months was already low.

The likelihood ratio in the segregation analysis $(L=41.3$; Tab. V) was much higher than our empirical threshold for a $1 \% \circ \alpha$ risk (Tab. I). The gene effect was about one ovulation on the observed scale, and seven sires out of 12 were found to be heterozygous with a probability estimated at over 0.98 . The number of heterozygous sires was respectively two, three and two for each founder family, which agrees with the independent results obtained in the F1 analysis also showing the three founders to be heterozygous.

\subsection{Ovulation of $\mathrm{F} 1 \times \mathrm{BC}$ daughters}

Table VI shows the first three records of daughters of BC ewes sired by F1 rams. Although the highest-ovulating $\mathrm{BC}$ ewes were chosen for mating with F1 rams after their first three records, the segregation analysis performed later when six records were available allowed us to classify some of these ewes as non-carriers. These mis-classifications concerned the few high-ovulating daughters of non-carrier F1 rams. Extremely high ovulation rates were observed repeatedly in some $\mathrm{F} 1 \times \mathrm{BC}$ ewes while others showed only low 
Table V. Results of segregation analyses on different samples.

\begin{tabular}{lcccc}
\hline Genotype & \multicolumn{2}{c}{ Lacaune } & $\begin{array}{c}\text { Booroola } \\
\text { Mérinos }\end{array}$ & $\begin{array}{c}\text { Booroola } \\
\text { Romanov }\end{array}$ \\
\hline Samples & $\begin{array}{c}\text { 3 founders sires } \\
\text { F1 q }\end{array}$ & $\begin{array}{c}12 \text { sons } \\
\text { BC } q\end{array}$ & 12 sires & 10 sires \\
& $11 \& 24$ & $11 \& 24$ & 13 & 13 \\
\hline Age of OR (months) & 5 & 6 & 3 & 2 \\
Records/ & 372 & 1236 & 360 & 293 \\
Total records & 2.01 & 1.56 & 1.26 & 2.87 \\
Ovulation mean & & & & \\
Gene effect & 1.72 & 2.22 & 3.20 & 3.46 \\
(underlying scale) & 1.09 & 1.05 & 1.15 & 1.81 \\
(observed scale) & 1.94 & 1.24 & 1.02 & 1.98 \\
$\mu++$ (obs. scale) & 3.03 & 2.29 & 2.17 & 3.79 \\
$\mu$ L+ (obs. scale) & $3 / 3$ & $7 / 12$ & $4 / 12$ & $5 / 10$ \\
nb. of heteroz. sires & 14.3 & 41.2 & 35.2 & 61.8 \\
Likelihood ratio & & & & \\
\hline
\end{tabular}

ovulation rates, with a high degree of repeatability within ewe $(r=0.70)$. The $++\mathrm{BC}$ ewes produced two groups of daughters: one group never displayed an ovulation rate higher than two (as with most of the $++B C$ ewes when they were young), while the other group reached as many as four and showed an OR pattern very close to that of the young $\mathrm{L}+\mathrm{BC}$ ewes. The few $\mathrm{L}+\mathrm{BC}$ ewes sired by $\mathrm{L}+$ rams produced three groups of daughters. A first group classified as ++ for the pattern of their OR similar to the pattern of $++\mathrm{BC}$; a second group classified as L+ for having the same pattern as their dam; and a third high-ovulating LL group which displayed ovulation which had never before been observed, either among F1 daughters of the founder rams or among the $\mathrm{BC}$ daughters of the $\mathrm{F} 1 \mathrm{rams}$, either during the first breeding season or even at the adult stage.

\subsection{DNA analyses}

Within the $\mathrm{F} 1$ and $\mathrm{BC}$ families, the BMPR-1B mutation responsible for the Booroola genotype $[20,30]$ was not found. Moreover, there was no cosegregation of ovulation with markers of the Booroola locus, which allowed us to exclude the involvement of the Booroola mutation and other possible alleles at the same locus. 
Table VI. Ovulation records of daughters of BC ewes sired by $\mathrm{L}+$ rams.

$\dagger$ Genotype and probability provided by the segregation analysis on OR records over two years.

\begin{tabular}{|c|c|c|c|c|c|c|c|}
\hline \multicolumn{3}{|c|}{ BC dam } & \multicolumn{2}{|c|}{ Dam OR } & \multicolumn{3}{|c|}{$\begin{array}{c}\text { First three OR } \\
\text { of } \mathrm{F} 1 \times \mathrm{BC} \text { Daughter } \\
\text { per supposed genotype }\end{array}$} \\
\hline Number & Genotype $^{\dagger}$ & $\mathrm{L}+$ Prob. $^{\dagger}$ & 1st year & 2nd year & LL & L+ & ++ \\
\hline 982054 & L+ & 1.00 & 44 & 134 & 64 & & \\
\hline 982012 & $\mathrm{~L}+$ & 1.00 & 432 & 23 & 656 & 323 & \\
\hline 982073 & $\mathrm{~L}+$ & 0.99 & 224 & 422 & 1155 & & \\
\hline 982055 & $\mathrm{~L}+$ & 0.93 & 223 & 12 & 346 & 333 & \\
\hline 982059 & $\mathrm{~L}+$ & 0.92 & 212 & 322 & 533 & & \\
\hline 982036 & L+ & 0.85 & 132 & 22 & 636 & 434 & \\
\hline 982136 & $\mathrm{~L}+$ & 0.85 & 222 & & 543 & & \\
\hline 982089 & $\mathrm{~L}+$ & 0.92 & 221 & 223 & & 422 & \\
\hline 982115 & $\mathrm{~L}+$ & 0.94 & 222 & 333 & & & 222 \\
\hline 982003 & $\mathrm{~L}+$ & 0.92 & 231 & 2 & & & 211 \\
\hline 982167 & ++ & 0.01 & 222 & 12 & & 233 & \\
\hline 982167 & ++ & 0.01 & 222 & 12 & & 412 & \\
\hline 980109 & ++ & 0.00 & 122 & 222 & & 412 & \\
\hline 980187 & ++ & 0.00 & 222 & 222 & & 333 & \\
\hline 980270 & ++ & 0.00 & 222 & 242 & & 322 & \\
\hline 980270 & ++ & 0.00 & 222 & 242 & & 433 & \\
\hline 980043 & ++ & 0.00 & 122 & 121 & & & 112 \\
\hline 980043 & ++ & 0.00 & 122 & 121 & & & 222 \\
\hline 980080 & ++ & 0.00 & 222 & 112 & & & 222 \\
\hline 980160 & ++ & 0.00 & 322 & 122 & & & 111 \\
\hline
\end{tabular}

\section{DISCUSSION}

Natural ovulation rates observed in the hyper-prolific ewes were higher than any value reported in the literature, and even higher than ovulation rates recorded in prolific Romanov ewes introgressed with the $\mathrm{FecB}$ Booroola gene [9].

The low response of F1 to the first synchronisation treatment was due to the effects of age and season. In the second year, the ovulation rate was higher and consequently variability also increased. But this increase led to a clearer 
discrimination among the ewes rather than a higher residual. There was thus a high degree of repeatability.

The lower ovulation rate of $\mathrm{BC}$ ewes compared to $\mathrm{F} 1$ ewes shows the polygenic effects of the selection undertaken in this population since 1975 when the selection for prolificacy was initiated. The genetic progress assessed using an animal model on the whole population under selection showed an increase of 0.02 extra lambs per lambing each year [9].

For the three founders, we observed a heterogeneous ovulation rate within each family. Assuming the existence of a major gene allowed us to discard two hypotheses: that high ovulation rates are not controlled by a recessive allele, and that the major gene is autosomal and not carried by the $\mathrm{X}$ chromosome as the Inverdale gene evidenced in the Romney population by Davis et al. [6, 8] and Galloway et al. [11], or the putative imprinted Woodlands gene also strongly suggested by Davis et al. [5].

There is a considerable difference in the mean OR among the twelve families, and except for progeny of the sons born of Gebro Lacaune ewes and progeny tested on Gebro Lacaune ewes, there is a clear relationship between the least square means and the coefficient of variation. The polygenic background of Gebro Lacaune ewes is slightly more prolific than that of the Dairy Lacaune ewes, which merely explains the special situation of the Gebro crossed animals.

Estimated repeatability was high $(r=0.48)$ and agrees with the estimate obtained in F1 ewes. This value is higher than the value of 0.20 to 0.40 for populations where there is no evidence of segregation of a major gene [10,14, 25]. Moreover, heritability, although estimated on a very small and specific genetic sample, is high $\left(h^{2}=0.30\right)$ for this trait compared to values in the literature cited by Hanrahan and Quirke [15].

Results of the segregation analyses performed on two quasi-independent samples ( $\mathrm{F} 1$ and $\mathrm{BC}$ populations) were very similar, confirming their validity. In contrast with expectations from the breeding values estimated by a heteroscedastic model through daughter litter size [27], the segregation analyses established the genotype of the three founders as heterozygous. The weak relationship between ovulation rate and litter size explains this discrepancy and clearly shows that mere observations of litter size obtained on farms are of little help in detecting major genes for ovulation.

The software used for the segregation analysis did not provide a statistical test since the distribution of the likelihood ratio is only roughly a Chi-square distribution. Following the example of Ilahi et al. [16], an empirical test performed on repeated simulations based on the true pedigree and performance structures yielded a distribution of the likelihood ratios under $\mathrm{HO}$, and the rejection thresholds. However, in contrast with Ilahi et al. [16], these rejection thresholds were only slightly higher than those provided by the Chi2 distribution, perhaps due to the numbers and structure of the performance 
associated with the very simple experimental design. It could be interesting to investigate in the future the use of MCMC techniques and Bayes factor that could overwhelm the problem of simulations needed to obtain the test distributions. The entire data set could also be treated this way, considering father and grandfather path at the same time.

From the two segregation analyses, it seems that the gene effect is about one extra ovulation at the heterozygous level. The observed heterogeneity of the ovulation rate within $\mathrm{F} 1$ and $\mathrm{BC}$ families proves that the allele controlling high ovulation rates is neither recessive nor dominant. We can suppose that the effect is merely additive as for the Booroola $F e c B$ gene. The very high repeatability of ovulation rates observed within $\mathrm{BC} \times \mathrm{F} 1$ ewe lambs and some very high observations cannot be explained by mere polygenic inheritance but is fully consistent with the segregation of a co-dominant major gene. In this small group, we were able to classify L+ and LL ewes with the same criteria as Davis et al. [7] used for Booroola FF ewes, and the proportions of each genotype agreed with expectations. At this stage, the Lacaune major gene seems to have similar effects to the Booroola gene, either at a heterozygous or a homozygous level.

Extremely high ovulation rates (OR $>10)$ observed repeatedly in the small group of hyper-prolific Lacaune ewes are not in accordance with a mere additive effect of the gene found at a heterozygous level in "F1" and in "BC" ewes. That leads us to suppose a more complex phenomenon: the simplest would be a multiplicative effect of the gene at the homozygous level, but the existence of several alleles of the same gene, or even involvement of other major genes, cannot be discarded.

Since the polymorphism observed around the locus of the BMPR-1B gene, responsible for the Booroola genotype, is fully independent of the ovulation phenotypes in $\mathrm{F} 1$ and $\mathrm{BC}$ populations, it is clear that the new Lacaune major gene is not close to the Booroola $\mathrm{FecB}$ locus. Complementary analyses with a large set of DNA markers have already been undertaken. Estimates of the allelic frequencies in the OVI-TEST Lacaune population and their effect on the genetic background of this population will be available only when close markers of this gene are found.

\section{CONCLUSION}

Evidence of a new major gene affecting ovulation has been found in the Lacaune population, using a statistical approach. This study confirms the previous results obtained in preliminary data of this program and presented by Bodin et al. [3]. Before proposing decisions about its possible interest for breeders, more research is needed to study its frequency in the population under control, its effect on homozygous ewes and the relationship with other traits. 


\section{ACKNOWLEDGEMENTS}

The authors acknowledge the financial support of the Conseil Régional de Midi-Pyrénées, the OVI-TEST Cooperative and the staff of the Langlade experimental farm who take care of the animals. They also thank J. Rallières for her technical assistance.

\section{REFERENCES}

[1] Bodin L., Bibé B., Blanc M.R., Ricordeau G., Genetic correlation relationship between prepuberal plasma FSH levels and reproductive performance in Lacaune ewe lambs, Genet. Sel. Evol. 20 (1988) 489-498.

[2] Bodin L., Chemineau P., Premiers résultats d'un testage en ferme sur l'aptitude au désaisonnement en race Lacaune, Mémoire de fin d'études Ensat: Inra Itovic, 1976.

[3] Bodin L., Elsen J.M., Poivey J.P., SanCristobal-Gaudy M., Belloc J.P., Eychenne F., Hyper-prolificacy in the French Lacaune sheep breed; a possible major gene, in: Proceedings of the 6th WCGALP, Armidale, 11-16 January 1998, University of New England, Armidale Australia, vol. 27, pp. 11-14.

[4] Bradford G.E., Quirke J.F., Sitorus P., Inonou I., Tiesnamurti B., Bell F.L., Fletcher I.C., Torell D.T., Reproduction in Javanese sheep: evidence for a gene with large effect on ovulation rate and litter size, J. Anim. Sci. 63 (1986) 418-431.

[5] Davis G.H., Dodds K.G., Wheeler R., Jay N.P., Evidence that an imprinted gene on the X chromosome increases ovulation rate in sheep, Biol. Reprod. 64 (2001) 216-221.

[6] Davis G.H., McEwan J.C., Fennessy P.F., Dodds K.G., Farquhar P.A., Evidence for the presence of a major gene influencing ovulation rate on the $\mathrm{X}$-chromosome of sheep, Biol. Reprod. 44 (1991) 620-624.

[7] Davis G.H., Montgomery G.W., Allison A.J., Kelly R.W., Bray M.R., Segregation of a major gene influencing fecundity in progeny of Booroola sheep, N.Z.J. Agric. Res. 25, (1982) 525-529.

[8] Davis G.H., Shackell G.H., Kyle S.E., A putative major gene for prolificacy in Romney sheep, in: Elsen J.M., Bodin L., Thimonier J., Inra (Eds.), Proceedings of the 2nd International Workshop on Major Genes for Reproduction in Sheep, Toulouse, 16-18 July 1990, pp. 61-65.

[9] Elsen J.M., Bodin L., François D., Poivey J.P., Teyssier J., Genetic improvement of litter size in sheep, in: Proceedings of the 5th WCGALP, Guelph, University of Guelph, Canada, 1994, vol. 19, pp. 237-244.

[10] Eythorsdottir E., Adalsteinsson S., Jonmundsson J.V., Hanrahan J.P., Research work on the Icelandic Thoka gene, in: Elsen J.M., Bodin L., Thimonier J., Inra (Eds.), Proceedings of the 2nd International Workshop on Major Genes for Reproduction in Sheep, Toulouse, 16-18 July 1990, pp. 75-84.

[11] Galloway S.M., McNatty K.P., Cambridge L.M., Laitinen M.P.E., Juengel J.L., Jokiranta T.S., McLaren R.J., Luiro K., Dodds K.G., Montgomery G.W., Beattie A.E., Davis G.H., Ritvos O., Growth differentiation factor 9B mutations cause 
increased ovulation rate and infertility in a dosage-sensitive manner, Nat. Genet. 25 (2000) 279-283.

[12] Hanrahan J.P., Evidence for single gene effects on ovulation rate in the Cambridge and Belclare breeds, in: Elsen J.M., Bodin L., Thimonier J., Inra (Eds.), Proceedings of the 2nd International Workshop on Major Genes for Reproduction in Sheep, Toulouse, 16-18 July 1990, pp. 93-102.

[13] Hanrahan J.P., Owen J.B., Variation and repeatability of ovulation rate in Cambridge ewes, Anim. Prod. 40, (1985), 529 abstr.

[14] Hanrahan J.P., Quirke J.F., Contribution of variation in ovulation rate and embryo survival to within-breed variation in litter size, in: Land R.B., Robinson D.W. (Eds.), Genetic of Reproduction in Sheep, Butterworths, London, 1985, pp. 193201.

[15] Hanrahan J.P., Quirke J.F., Breeding season and multiple births in small ruminants, in: Proceedings of the 3rd WCGALP, Lincoln Nebraska, 16-22 July 1986, vol. 11, pp. 30-45.

[16] Ilahi H., Manfredi E., Chastin P., Monod F., Elsen J.M., Le Roy P., Genetic variability in milking speed of dairy goats, Genet. Res. Camb. 75 (2000) 315319.

[17] Jonmundsson J.V., Adalsteinsson S., Single gene for fecundity in Icelandic sheep, in: Land R.B., Robinson D.W. (Eds.), Genetics of reproduction in sheep, Butterworths, London, 1985, pp. 159-168.

[18] Le Roy P., Elsen J.M., First statistical approaches of the major gene detection with special reference to discrete traits, in: Elsen J.M., Bodin L., Thimonier J., Inra (Eds.), Proceedings of the 2nd International Workshop on Major Genes for Reproduction in Sheep, Toulouse, 16-18 July 1990, pp. 431-440.

[19] Le Roy P., Naveau J., Elsen J.M., Sellier P., Evidence for a new major gene influencing meat quality in pigs, Genet. Res. Camb. 55 (1990) 33-40.

[20] Mulsant Ph., Lecerf F., Fabre S., Schibler L., Monget Ph., Lanneluc I., Pisselet C., Riquet J., Monniaux D., Callebaut I., Cribiu E., Thimonier J., Teyssier J., Bodin L., Cognié Y., Chitour N., Elsen J.M., Mutation in bone morphogenetic protein receptor-IB is associated with increased ovulation rate in Booroola Merino ewes, PNAS, 98 (2001) 5104-5109.

[21] Numerical Algorithms Group, The NAG Fortran Library Manual, NAG Ltd. Oxford, 1990.

[22] Perret G., Bodin L., Mercadier M., Scheme for genetic improvement of reproductive abilities in Lacaune sheep, in: 43rd Annual meeting of the EAAP, 1992, Madrid, Spain.

[23] Piper L.R., Bindon B.M., Genetic segregation for fecundity in Booroola Merinos sheep, in: Barton R.A., Smith W.C. (Eds.), Proceedings of the World Congress on Sheep and Beef Cattle Breeding, 1982, Palmerston North, N.Z., pp. 395-400.

[24] Poivey J.P., Cournut J., Jullien E., Bibé B., Perret G., Elsen J.M., Berny F., Bouix J., Bodin L., Estimation of meat sheep breeding values in French on farm performance recording system, in: 41st Annual meeting of the EAAP, 1990, Toulouse, France.

[25] Quirke J.F., Bradford G.E., Famula T.R., Torell D.T., Ovulation rate in sheep selected for weaning weight or litter size, J. Anim. Sci. 61 (1985) 1421-1430. 
[26] Radomska M.J., Martyniuk E., Klewiec J., Knothe A., Inheritance of high prolificacy of the Olkuska sheep (preliminary results), J. Agric. Sci. 60 (1988) 597-598.

[27] SanCristobal-Gaudy M., Bodin L., Elsen J.M., Chevalet C., Genetic of litter size variability in sheep, Genet. Sel. Evol. 33 (2001) 249-271.

[28] SanCristobal-Gaudy M., Elsen J.M., Bodin L., Chevalet C., Prediction of the response to a selection for canalisation of a continuous trait in animal breeding, Genet. Sel. Evol. 25 (1998) 3-30.

[29] Titterington D.M., Smith A.F.M., Makov U.E., Statistical analysis of Finite Mixture Distribution, John Wiley, New York, 1985.

[30] Wilson T., Wu X.-Y., Juengel J.L., Ross I.K., Lumsden J.M., Lord E.A., Dodds K.G., Walling G.A., McEwan J.C., O’Connell A.R., McNatty K.P., Montgomery G.W., Highly prolific Booroola sheep hace a mutation in the intracellular kinase domain of bone morphogenetic protein $1 \mathrm{~B}$ receptor (ALK-6) that is expressed in both oocytes and granulosa cells, Biol. Reprod. 64 (2001) 1225-1235.

To access this journal online: www.edpsciences.org 